\title{
Disposal of flue gases in oil reservoirs with high-viscosity oil in order to increase oil recovery and improve the environmental situation
}

\author{
Evgeniy Shchesnyak ${ }^{1}$, Anatoliy Ryzhkov ${ }^{1}$, Iosif Ledovich ${ }^{1}$, Andrey Osipov ${ }^{1, *}$, \\ and Artur Musin ${ }^{2}$ \\ 'People's Friendship University of Russia (RUDN University), 6 Miklukho-Maklaya Street, \\ Moscow, 117198, Russian Federation \\ ${ }^{2}$ VNIIneft JSC, 10 Dmitrovskiy Proezd, Moscow, 127422, Russian Federation
}

\begin{abstract}
The reserves of highly viscous oils and natural bitumen are several times higher than the stocks of light oils. In the development of such oils by thermal methods, steam is produced, the development of which is accompanied by significant emissions into the atmosphere of flue gases, including carbon dioxide. According to estimates, the extraction of high-viscosity oils annually releases about 34.5 million tons of carbon dioxide into the atmosphere. However, carbon dioxide emissions from steam generation can be reduced to zero by injecting flue gases along with steam into the formation. In addition to environmental benefits, the technology of co-injection of water vapor and combustion gases (nitrogen and carbon dioxide) has a complex (thermal and physico-chemical) effect on the formation with a synergistic effect. The article is devoted to the analysis of the mechanisms affecting the increase in oil recovery during the co- injection of steam with flue gases, the description of equipment for the injection of flue gases into the reservoir, as well as the analysis of field experience in using this technology. The calculations for one of the fields of high-viscosity oil show the high efficiency of co-injection of water steam with flue gases.
\end{abstract}

\section{Introduction}

With the development of light oil reserves, the most important component of the raw material base not only in Russia, but also in a number of other oil-producing countries of the world, are stocks of highly viscous oils and natural bitumen. Their world total volume is estimated at 810 billion tons, which is almost five times the amount of residual recoverable reserves of low and medium viscosity oils, which is only 162.3 billion tons [1]. The annual production of heavy and bituminous oil in the world in 2000 amounted to more than 440 million tons, and the accumulated production of all time - more than 14 billion tons.

\footnotetext{
*Corresponding author: aosipov@ vniineft.ru
} 
According to [1], Canada has the largest reserves of heavy and bituminous oil, Venezuela has the second largest reserves of heavy and bituminous oil, wich are reserves located in the Orinoco bituminous belt. Mexico, the United States, Russia, Kuwait and China also have large reserves of heavy and bituminous oil.

When developing oil fields containing $\mathrm{BBH}$, thermal methods of enhanced oil recovery have no alternative at present. Among thermal methods, steam injection is the most common.

Currently, steam at the fields is produced by steam generators working on associated and natural gas. Steam generation by steam generators is accompanied by a significant emission of the flue gases into the atmosphere, including carbon dioxide. When producing 1 ton of steam, approximately $126 \mathrm{~kg}$ of carbon dioxide is formed.

In 2012, global oil production was estimated at 68.385 million tons due to steam-thermal methods [2]. Taking the average steam-oil ratio at the level of 4 tons of steam / ton of oil, we get an annual estimate of steam production in the amount of 273.5 million tons. When generating this amount of steam, 34.5 million tons of carbon dioxide is emitted into the atmosphere annually. Thus, during the extraction of oil by steam thermal methods there is a significant pollution of the atmosphere.

However, carbon dioxide emissions from steam generation can be reduced to zero by co-injecting flue gases with steam into the formation. In addition to environmental benefits, the technology of co-injection of water vapor and combustion gases (nitrogen and carbon dioxide) has a complex (thermal and physico-chemical) effect on the formation with a synergistic effect.

\section{Mechanisms to increase oil recovery}

Compared to using only steam, this technology has the following advantages [3]:

The tasks were solved for one of the fields of natural bitums of the Caribbean, the main characteristics of which are presented in Table 1.

- Simultaneous injection of the steam with the steam of products of combustion of fuel increases the oil displacement factor and, consequently, the rate of fluid withdrawal from the reservoir, reduces the steam-oil ratio and water-oil ratio. Gas-pressure mode, developing with the help of non-condensable gases (nitrogen, etc.), is one of the main factors for increasing the efficiency of gas-vapor pressure;

- Hydrocarbon-soluble carbon dioxide gas injection with steam contributes to an additional decrease in oil viscosity, an increase in its volume and the development of dissolved gas mode;

- Carbon dioxide injected with steam, dissolving in oil, additionally reduces its viscosity, increases its volume and contributes to the development of dissolved gas mode;

- An aqueous solution of carbon dioxide reacts with the carbonates of rocks and dissolves them. At the same time, the permeability of the reservoir and the injectivity of injection wells increase. In addition, carbon dioxide dissolved in the injected water prevents the clay from swelling;

- Increasing the radius of heat exposure;

- $\quad$ Reducing the volume of water in the oil-water emulsion due to less water injection;

- Improvement of steam dryness, increase in injection capacity of wells, increase in radius of heat exposure;

- Disposal of flue gases improves the environmental situation.

Let us dwell on some of the listed factors in more detail. 


\subsection{Increase of oil displacement factor}

As shown by numerous studies [3, 4], the oil displacement factor during co-injection of steam with flue gases is significantly higher (up to $68 \%$ absolute) as compared with just steam injection. So according to studies [3], the oil displacement factor increases from $47 \%$ when steam is injected up to $55.9 \%$ with joint co-injection of steam with flue gases (see Table 1). In [4], the growth of the oil displacement coefficient during the transition from steam injection to joint injection of steam and flue gases was $21.5 \%$ (see Table 2). In the work [5] it is indicated that at co-injection of steam with flue gases a synergistic effect is observed, that is, oil production at co-injection of steam with flue gases is more than the sum of oil production at separate injection of steam and flue gases (see Figure 1).

Table 1. The change in the oil displacement factor with the co-injection of steam with flue gases according to [3].

\begin{tabular}{|c|c|c|c|}
\hline Injected agent & $\begin{array}{c}\text { Ratio of flue gases to } \\
\text { steam }\left(\mathbf{n m}^{\mathbf{3}} \mathbf{\text { ton}}\right)\end{array}$ & $\begin{array}{c}\text { Displacement } \\
\text { factor, \% }\end{array}$ & $\begin{array}{c}\text { Increase displacement } \\
\text { factor, \% }\end{array}$ \\
\hline Steam & - & 47.0 & - \\
\hline \multirow{3}{*}{ Steam+ flue gases } & 10.3 & 79.0 & 68.1 \\
\cline { 2 - 4 } & 13.8 & 64.9 & 38.1 \\
\cline { 2 - 4 } & 23.5 & 55.9 & 18.8 \\
\hline
\end{tabular}

Table 2. The change in the oil displacement factor with the co-injection of steam with flue gases according to [4].

\begin{tabular}{|c|c|c|c|}
\hline Injected agent & $\begin{array}{c}\text { Ratio of flue gases to } \\
\text { steam }\left(\mathbf{n m}^{\mathbf{3}} / \mathbf{t o n}\right)\end{array}$ & $\begin{array}{c}\text { Displacement } \\
\text { factor, \% }\end{array}$ & $\begin{array}{c}\text { Increase displacement } \\
\text { factor, \% }\end{array}$ \\
\hline Water & - & 39.6 & - \\
\hline Steam & - & 44.3 & 4.7 \\
\hline Steam+ flue gases & 1 & 61.1 & 21.5 \\
\hline
\end{tabular}

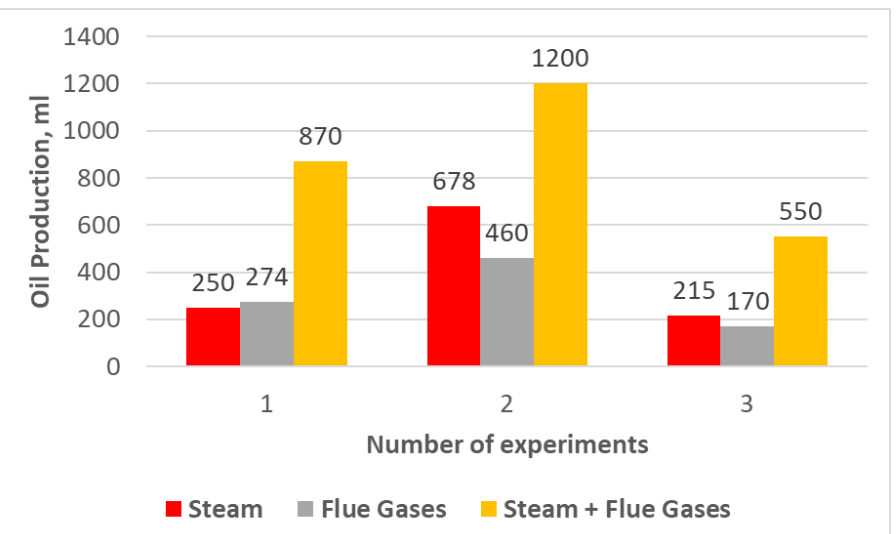

Fig. 1. Oil production by steam injection, flue gas, co-injection of steam with flue gases according to [5].

\subsection{Dissolving carbon dioxide in oil}

Studies conducted in $[4,6]$ show that up to $15 \mathrm{~m} 3$ of flue gases dissolve in 1 ton of oil, reducing the viscosity of oil to 54\% (Figure 2-3). This reduces the density of oil and increases its volume (Figure 4). 


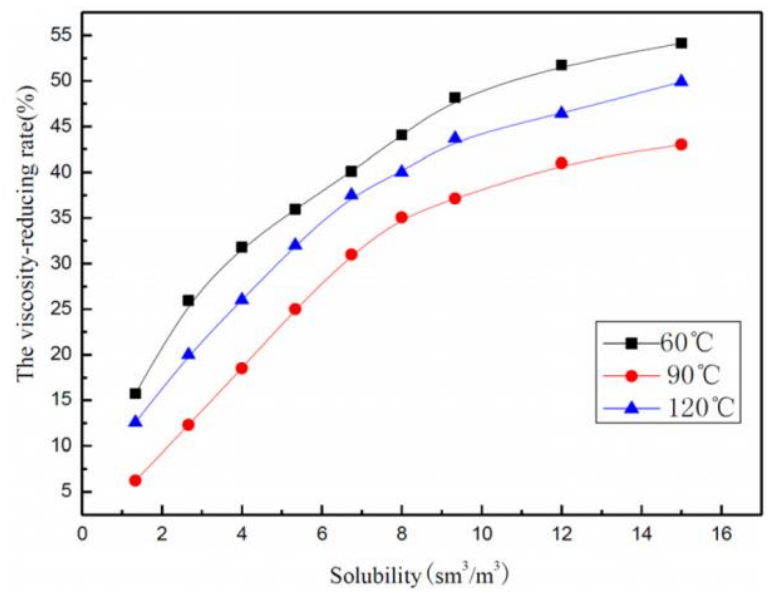

Fig. 2. Decrease in oil viscosity when flue gases dissolve in it according to [6].

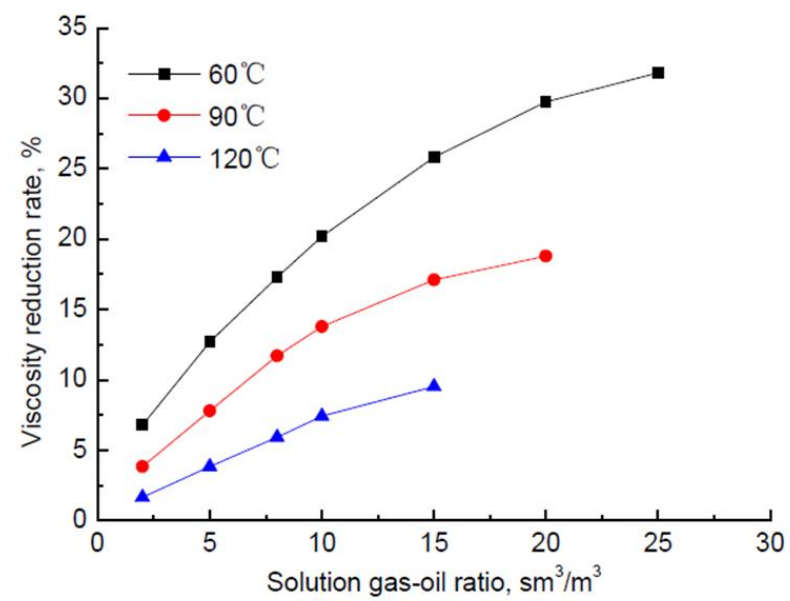

Fig. 3. Decrease in oil viscosity when flue gases dissolve in it according to [4].

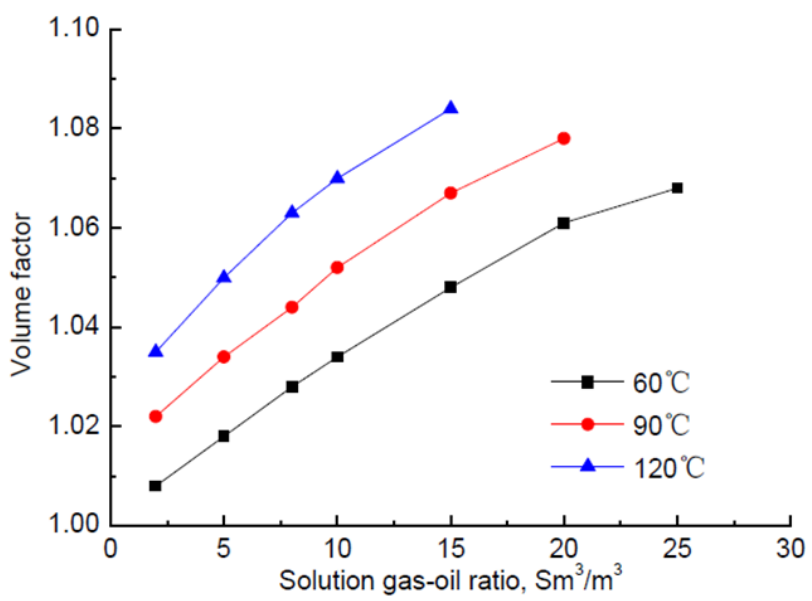

Fig. 4. Increasing the volume of oil during the dissolution of flue gases in it according to [4]. 


\section{Field test}

Field studies of the co-injection of steam with flue gases show the high efficiency of the this technology.

The technology was tested in Russia in Krasnodar and the Komi Republic. At the Krasnodar Zybza-Gluboky Yar field [7], in one area the steam oil ratio decreased from 5.7 to 1.7 during the co-injection of steam with flue gases. At another site, the steam-oil ratio was also low and amounted to 2.2 tons of steam per ton of oil.

At the Usinskoye field [8], flue gases have been injected with steam for 21 days, during this time the steam oil ratio decreased from 5 to 4.3 , and oil production has increased by 7.3\%. Gas utilization at this was $70 \%$.

In the Chinese offshore field Bohai, a mobile steam and gas generator was used, which allowed it to be placed on the offshore platform [9]. Cyclic treatments of horizontal wells with a mixture of steam and flue gases have been carried out for 2 years. Oil production rate has increased by 3 times compared with the natural mode.

\section{Flue gas injection equipment}

The traditional equipment for pumping flue gases is a high-pressure compressor.

An innovative slot-type jet compressor was used at the Usinskoye field [8], in which flue gases were sucked up using steam energy, which allowed flue gases to be pumped without additional energy costs. The vapor pressure at the same time will varied from $17 \mathrm{MPa}$ at the entrance to the compressor to $5.7 \mathrm{MPa}$ at the exit from it.

In China, a steam and gas generator with diesel fuel was used at the Bohai field to generate and inject the gas-vapor mixture [5].

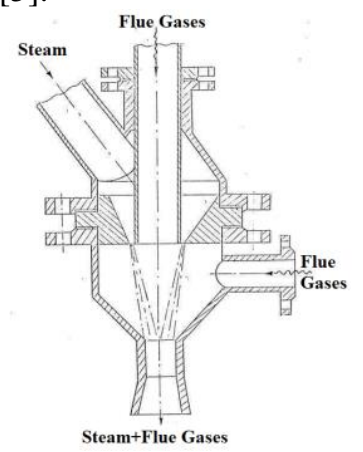

Fig. 5. Schematic diagram of a slit jet compressor for the co-joint injection of steam with flue gases according to [8].

\section{Assessment of the potential effect of flue gas utilization in oil reservoirs}

An assessment of the potential effect of co-injection of steam with flue gases was made for one of the deposits of natural bitumen in the Caribbean basin, the main characteristics of which are presented in Table 3. The cyclic steam injection in horizontal wells was taken as the basic development method. Hydrodynamic modeling was carried out on a sector model with geometrical dimensions $1000 \times 100 \times 86 \mathrm{~m}(\mathrm{X} * \mathrm{Y} * \mathrm{Z})$ in the thermal simulator "CMG STARS" (Computer Modeling Group). The number of cells in the sector model was: along the $\mathrm{X}$ axis -20 , along the $\mathrm{Y}$ axis -40 , along the $\mathrm{Z}$ axis -110 . The characteristic dimensions 
of the cells: along the axis of the wells $-50 \mathrm{~m}$, perpendicular to the axis of the wells $-2.5 \mathrm{~m}$, vertical $-0.8 \mathrm{~m}$. The model adopted an equilibrium initialization. At the initial moment of time, the fields of distribution of pressure and fluid saturations should provide a static equilibrium of the model at which the phases are stationary. Achieving such a state is possible using the option of gravitational-capillary equilibrium, present in all modern simulators. The initial distribution of oil saturation of the reservoir was calculated according to the data of the digital geological model. The initial pressure distribution was constructed as a function of depth and saturation according to the known initial reservoir pressure at a certain absolute depth of the development object. The dependence of oil viscosity on temperature, used in the model, is shown in Figure 6. The dependence of the solubility of carbon dioxide in oil on pressure and the dependence of the viscosity of oil on carbon dioxide dissolved in it at different temperature were taken according to studies [10-12] and are presented in Figures 7-8. In the calculations, the complete utilization of the flue gas from the steam generator was assumed; therefore, the composition of the gas-vapor mixture injected into the reservoir was as follows: $\mathrm{CO}_{2}-3.8 \mathrm{~mol} \%, \mathrm{~N}_{2}-28.1 \mathrm{~mol} \%, \mathrm{H}_{2} \mathrm{O}-68.1 \mathrm{~mol} \%$.

Figure 9-10 shows the dynamics of cumulative oil production and cumulative steam oil ratio for variants with steam injection and with co-injection of flue gases and steam. As can be seen from the figures, over the entire period of the development, the dynamics of the cumulative oil production of the variant with co-injection of steam and flue gases exceeds that of the variant with the injection of just steam. Cumulative oil production at the end of the field development in the variant with steam and flue gas injection $\left(301.5\right.$ thousand $\left.\mathrm{m}^{3}\right)$ is $9.5 \%$ more than in the variant with just steam injection $\left(274.4\right.$ thousand $\left.\mathrm{m}^{3}\right)$. The cumulative steam-oil ratio at the end of the field development in the variant with steam and flue gas injection $\left(3.9 \mathrm{~m}^{3} / \mathrm{m}^{3}\right)$ is $12.8 \%$ lower than in the variant with just steam injection $\left(4.4 \mathrm{~m}^{3} / \mathrm{m}^{3}\right)$, which indicates a significant reduction in energy consumption for steam generation production of 1 ton of oil.

Table 3. Basic geological and physical characteristics.

\begin{tabular}{|c|c|c|c|}
\hline No. & Significative & Units & Value \\
\hline 1 & Average depth & $\mathrm{m}$ & 600 \\
\hline 2 & Type of reservoir & & massive \\
\hline 3 & Type of collector & $\mathrm{m}$ & Carbonate \\
\hline 4 & Average total thickness & $\mathrm{m}$ & 73 \\
\hline 5 & Average effective oil saturated thickness & unit fraction & 0.38 \\
\hline 6 & Porosity & unit fraction & 0.61 \\
\hline 7 & Oil saturation & $10^{-12} \mathrm{~m}^{2}$ & 0.869 \\
\hline 8 & Permeability & unit fraction & 0.63 \\
\hline 9 & Net to gross & unit fraction & 10 \\
\hline 10 & Average number of permeable intervals & ${ }^{0} \mathrm{C}$ & 36 \\
\hline 11 & Initial reservoir temperature & $\mathrm{MPa}$ & 6.16 \\
\hline 12 & Initial reservoir pressure & $\mathrm{mPa}{ }^{*} \mathrm{~s}$ & 35552 \\
\hline 13 & Oil viscosity in reservoir conditions & $\mathrm{kg} / \mathrm{m}^{3}$ & 1029 \\
\hline 14 & Oil density in reservoir conditions & $\mathrm{kg} / \mathrm{m}^{3}$ & 1021 \\
\hline 15 & Oil density in surface conditions & $\mathrm{unit} \mathrm{fraction}_{1}$ & 1.0095 \\
\hline 16 & Oil volume factor & $\mathrm{MPa}^{3}$ & 1.95 \\
\hline 17 & Bubble point pressure & $\mathrm{m}^{3} / \mathrm{m}^{3}$ & 2.40 \\
\hline 18 & Gas oil ratio & & \\
\hline
\end{tabular}




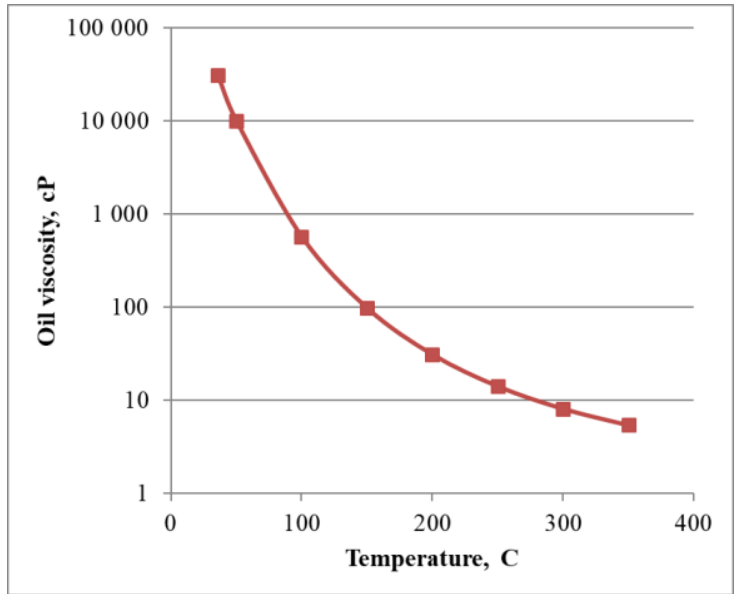

Fig. 6. Dependence of the degassed oil viscosity on temperature.

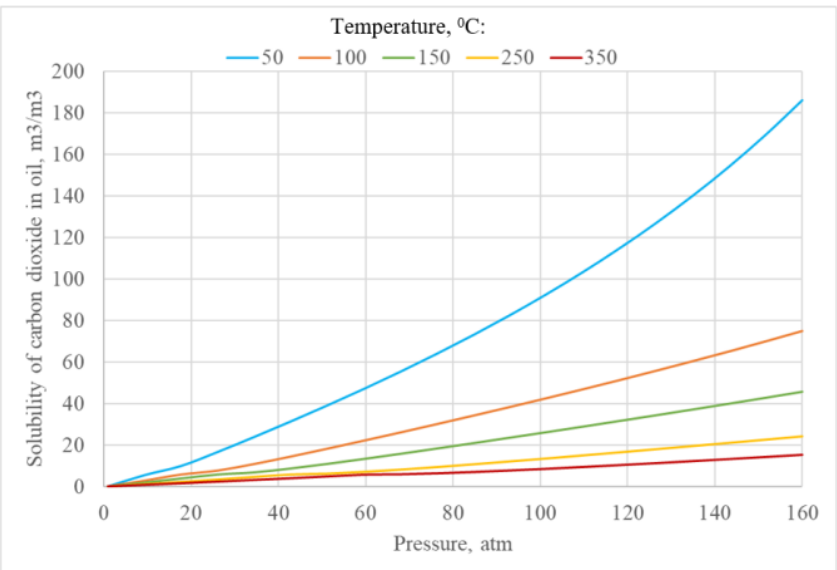

Fig. 7. The dependence of the solubility of carbon dioxide in oil from pressure at different temperature.

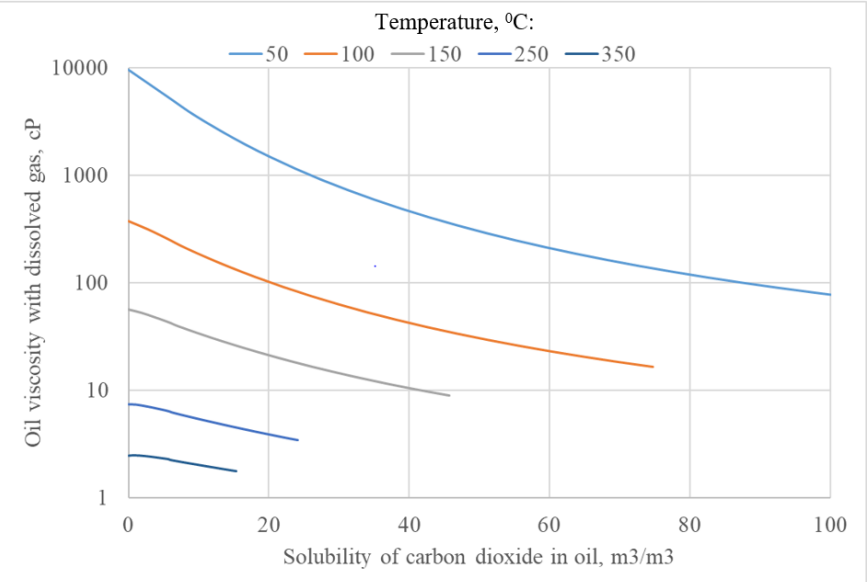

Fig. 8. Dependence of oil viscosity on the amount of gas dissolved in it at different temperature. 


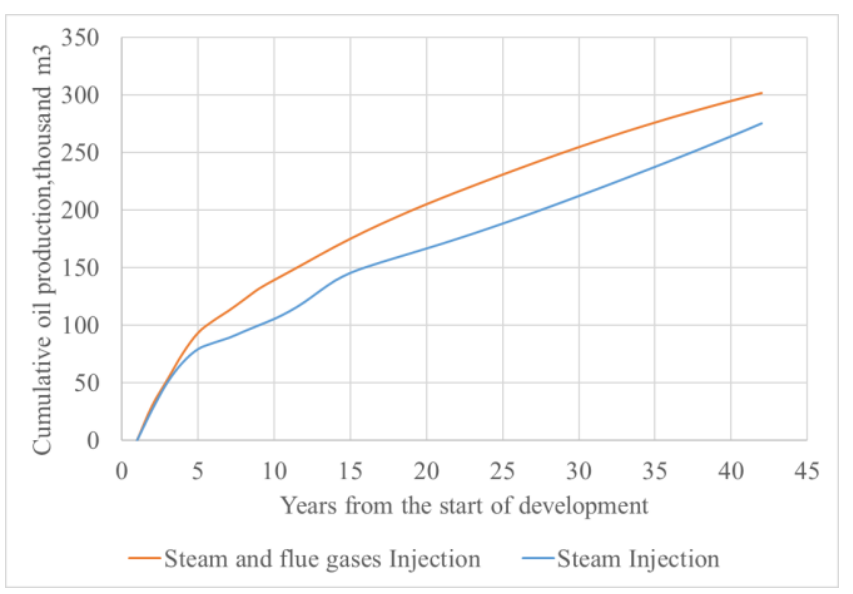

Fig. 9. Dynamics of cumulative oil production for steam injection and for co-injection of steam and flue gases.

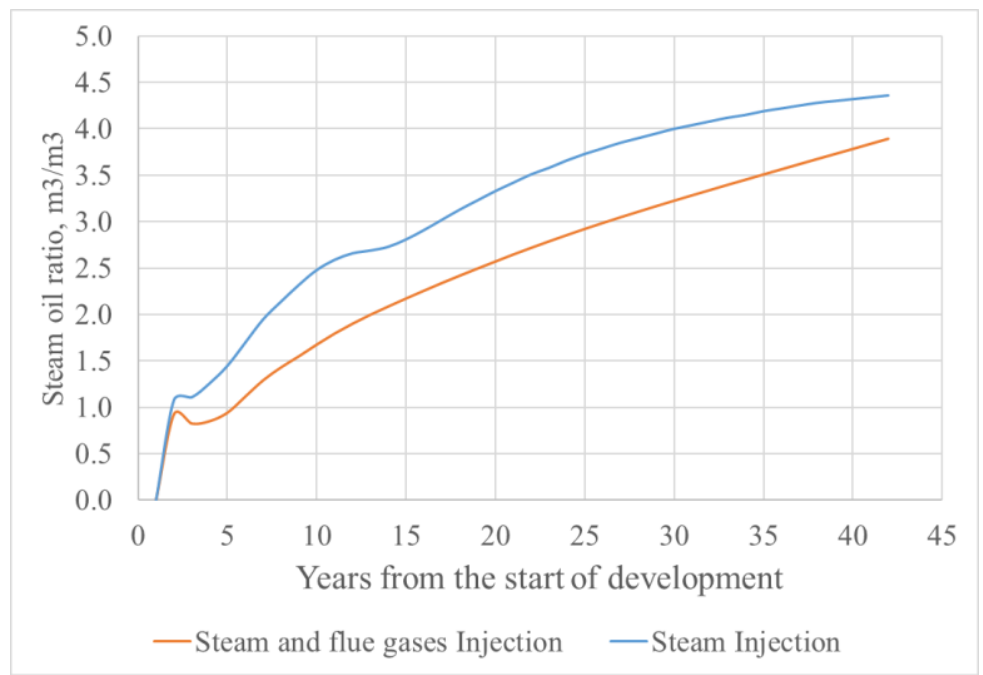

Fig. 10. Dynamics of cumulative steam oil ratio for steam injection and for co-injection of steam and flue gases.

\section{Conclusions}

As a result of the research, the following conclusions were made:

- Extraction of high-viscosity oils, the reserves of which exceed the reserves of light oils several times, with the help of thermal methods is accompanied by significant emissions of carbon dioxide into the atmosphere due to the production of steam.

- Modern equipment allows to dispose flue gases by pumping them into the reservoir. This increases oil recovery, mainly due to a decrease in oil viscosity when carbon dioxide is dissolved in it. There is also a synergistic effect, i.e., oil production at co-injection of steam with flue gases is more than the sum of oil production at separate injection of steam and flue gases.

- The calculations carried out on the model for a high-viscosity oil field confirm the high efficiency of the co-injection of flue gases with steam compared to the injection of just 
steam. Cumulative oil production increases by $9.5 \%$, cumulative steam-oil ratio decreases by $12.8 \%$.

- In connection with the above, the technology of co-injection of steam with flue gases is able to solve environmental problems and increase the oil recovery of highly viscous oils.

\section{References}

1. R. A. Maksutov, G. I. Orlov, A. V. Osipov, Oil industry 2, 34-37 (2007)

2. L. Koottungal, Oil and Gas Journa, 57-69 (2012)

3. L. S. Monte-Mor, Laboratory study on steam and flue gas co-injection for heavy oil recovery (SPE-165523-MS, 2013)

4. Z. Wang, Research on enhancing heavy oil recovery mechanism of flue gas assisted steam flooding (CMTC-486093-MS, 2017)

5. L. Zhong, Investigation on principles of enhanced offshore heavy oil recovery by coinjection of steam with flue gas (SPE 165231, 2013)

6. C. Zhang, Performance of Flue Gas and Foam Assisted Steam Huff and Puff with Horizontal Well in Enhanced Recovery of Fengcheng Oil Field (SPE-170105-MS, 2014)

7. D. G. Antoniadi, Increased oil recovery by gas and steam-gas methods (Moscow, JSC, Publishing House of the Subsurface, 1998)

8. V. B. Kozlov, The complex of technical and technological solutions for the optimization of thermal effects on deep-lying deposits of high-viscosity oil (using the PermianCarboniferous deposit of the Usinsk oil field as an example) (Ph. D. Thesis, Usinsk, 2004)

9. L. Zong, Investigation on Principles of Enhanced Offshore Heavy Oil Recovery by Coinjection of Steam with Flue Gas (SPE 165231-MS, 2013)

10. A. K. Mehrotra, W. Y. Svrcek, Journal of Canadian Petroleum Technology 21, 95-104 (1982)

11. F. T. H. Chung, R. A. Jones, H. T. Nguyen, SPE Reservoir Engineering 3, 3, 822-828 (1988)

12. M. K. Emera, H. K. Sarma, JCPT 47, 52-61 (2008) 